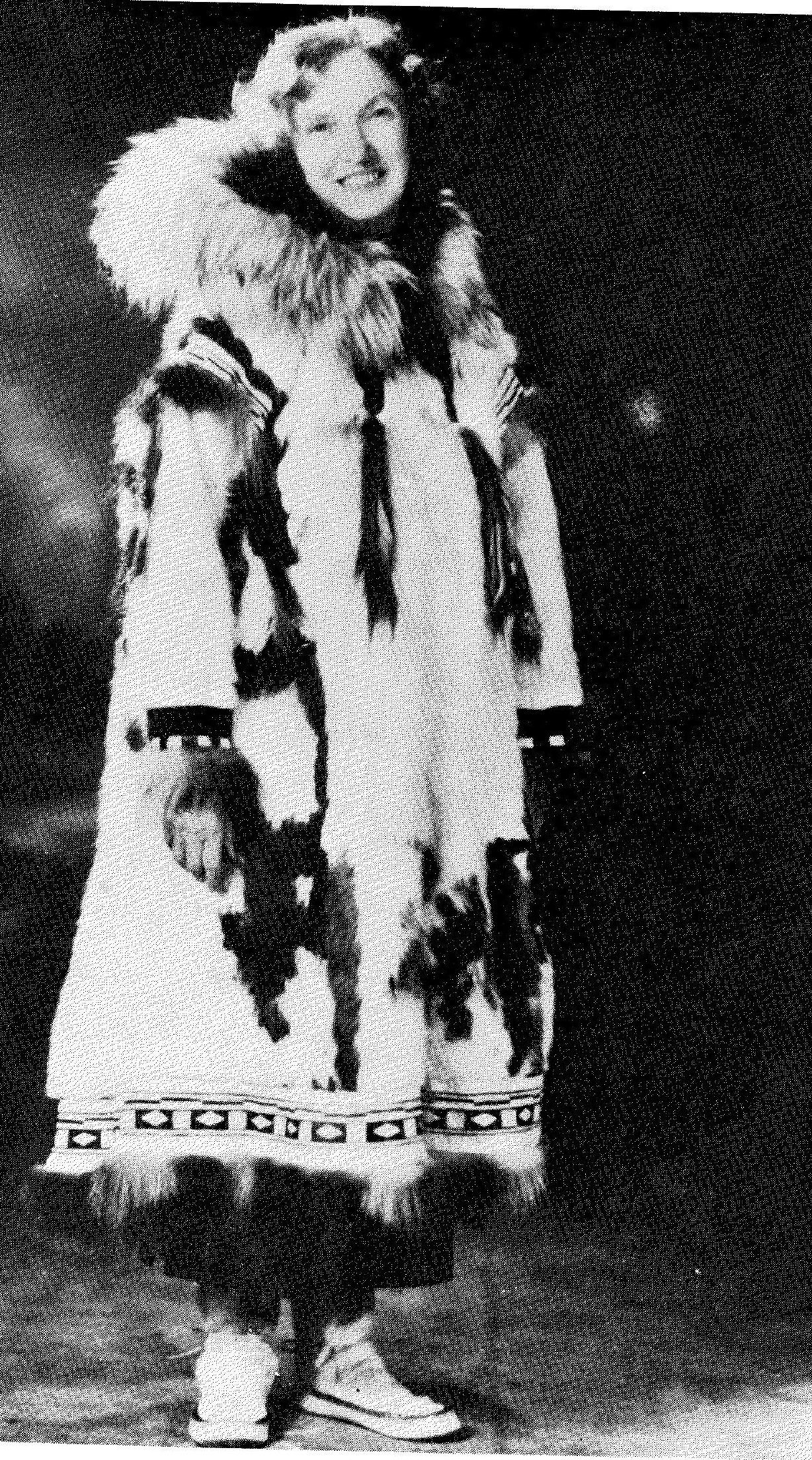

Mollie Ward Greist 


\title{
On Some White Women in the Wilds of Northern North America
}

\author{
JOSEPHINE W. BOYD
}

"Great God! This is an awful place!" were words used by Scott at the South Pole (Pound 1967), but they could have come just as well from the lips of a white woman on finding herself in the proximity of either Pole.

Although some Viking woman undoubtedly preceded her onto the North American continent, Natalya Shelekhov became the first European female in Alaska when she and her merchant husband spent four years (1783-1787) on Kodiak Island. (He later founded the Russian-American Company.) Natalya's visit did not precipitate a female invasion, however, and Russian merchants largely kept to native "wives" in North America (Chevigny 1942).

In Canada, at the beginning of the nineteenth century, Indian women likewise became the "country" (common law) wives of fur traders and trappers of both the Hudson's Bay Company and the North West Company; they were known as petticoat politicians because of their unofficial, though pronounced, influence on their mates' decisions. By the 1820's men started bringing European women to Indian country, but by 1825 one, Captain R. P. Pelley, Governor of Red River, was forced to return to England with his wife, whose health had given out after she had braved the wilds for two years. The Bay Company's Overseas Governor, George Simpson, nevertheless decided to bring out his 18-old English wife, Frances, in 1830. A delicate constitution and sheltered upbringing hardly fitted her for the role of governor's lady in the wilds of Rupert's Land, however, and she returned to England for good in 1833 (Van Kirk 1972). J. G. McTavish brought out his Catherine in 1830 also. They made a home on the shores of Hudson Bay at Moose Factory and remained there until even Catherine's stout Scottish temperament had had enough; they moved to a farm on the Ottawa River in the settled part of Canada in 1835.

Although very few white women lived in Indian country during this period (and the Simpson, McKenzie, Jones and Cochrane wives were the only ones living at Red River during the spring of 1831), more were steadily arriving, as it now became fashionable for Company officers to have European wives. Their coming brought an end to the earlier and freer social customs of the fur trade. Indeed, "country" marriages with Indian and mixed-blood women became unacceptable; the native skills of such partners were no longer needed in settled areas. By this time the area known as Rupert's Land was very largely populated by partiallywhite individuals, most of whom had no place in an all-white ruling society. A small number of men lived with, or were married to, mixed-blood women, and their offspring educated in Canada or England, but for the most part such relationships were abandoned with the coming of white women (Van Kirk 1972). The European wife, in her turn, was often a misfit in the new world, terrified to look about her for fear of seeing some of the results of her husband's earlier liaisons. 
The most pronounced impression made by any white woman on the northern part of the continent was that of one who never actually set foot in North America. Jane Griffin became Sir John Franklin's second wife after he had already made two unsuccessful trips in search of the Northwest Passage (Dayton 1859). When Sir James C. Ross declined to lead the next expedition, the ambitious wife successfully campaigned to have 59-year-old Sir John put in charge (Caswell 1971). He left England on 19 May 1845 never to return, and Lady Franklin carried her grief to both the government and the public, causing many ships to put out in quest of her husband. She contributed her own and her husband's money and resources towards the search, in the course of which several men lost their lives (M'Clintock 1860). After some five or six years it had manifestly become futile, and there was some justification for the suspicion that the lady was more interested in establishing her beloved husband as the discoverer of the Northwest Passage than in the discovery of his remains. Whatever may have motivated her, Lady Franklin undoubtedly stimulated much exploration of the Canadian northland.

The latter decades of the nineteenth century brought some of the first white women to the arctic coast of North America. They were whaling captains' wives, often with small children. They stayed aboard ship much of the time, making only brief visits ashore at places like Brower's whaling station (Cape Smythe, Barrow, Alaska), yet they were able to carry on gossip, and even begin a few feuds with other captains' wives. On more than one occasion Charles Brower had to help icebound whalers' families pass the winter at his station. He records that a Mrs. Cook, wife of the wrecked Laura Matson's skipper, lived at his station in 1905-06 and came back with Captain Cook on the Bowhead to spend the winter of 1906-07 on Herschel Island. In 1908-09, Charlie grudgingly provided a refuge for Captain Boggs and his wife and children who had come to the station quite destitute.

During the 1890's gold and all the dreams that went with it brought considerably more women north than did whaling captains. Camp followers, dance hall girls, aspiring lady miners, and an exceptionally large number of husband-hunting widows tried to reach the Yukon during that decade, but not many got beyond Seattle (Berton 1967). One widow, Harriet Pullen, got as far as Skagway, Alaska, and made her fortune freighting cargo during the daytime and selling home-made apple pies at night. She stayed in Skagway the rest of her life, becoming the town's most distinguished citizen.

Belinda Mulroney, a legendary figure of the Klondike stampede, invested a hard-earned $\$ 5,000$ (she had worked as a ship's stewardess, purchasing agent and coastal trader) in cotton cloth and hot water bottles which she and two Indians floated down river to Dawson, to make for her a 600 percent profit (Berton 1967). This bonanza enabled her to open a lunch stand and a roadhouse, to start a home-building business, and even to acquire an interest in several mines. She became proprietress of Dawson's most luxurious hotel, the only woman miningmanager in the territory, and the richest of her sex in the Klondike. She married, left the North by way of the boom at Tanana, Alaska, and retired to a ranch in Washington State.

Ladylike society in the Canadian wilds did not consist entirely of the somewhat 
fragile wives of early Bay Company officers. Mary Hitchcock, widow of a U.S. admiral, chose Dawson in 1898 for her annual visit to a select, educational and interesting watering place: She arrived sporting the latest frontier fashions, including a cartridge belt supporting huge revolvers. She brought as personal possessions "two Great Danes, canaries, pigeons, a portable bowling alley, zither, mandolin, paté, truffles, oysters, and vintage wines . .." along with an enormous tent where she and a female companion held court with Dawson's finest (Berton 1967).

By the turn of the century women were coming into Nome, Alaska, for the same reason that they had come to Dawson - the lure of gold - and within another three years families were settling in the area. Among them was the highlyrespected Lomen family, which included a wife and daughter (a daughter-in-law followed in 1905) (Lomen 1954).

The 1890's saw white women venturing into still another part of the far north. Josephine Peary, married to the explorer for $3 \frac{1}{2}$ years, accompanied him on the Greenland expedition of 1891-92 (Peary 1893). Peary probably hoped she would see to such domestic matters as sewing, cooking, and cleaning. Jo, a nonbeliever in the traditional role of women, however, left the sewing to Eskimo women and the cooking to Peary's assistant, Matt Henson, reserving to herself the task of changing curtains more frequently than had any other woman in the recorded history of the North. She never became entirely adjusted to her surroundings. Throughout her stay, if an Eskimo entered her quarters, she felt it necessary to immediately disinfect the room with a mercury compound; and both Pearys, before getting into their sleeping bags at night, stripped, and rubbed themselves all over with alcohol to avoid any contagion from the Eskimos. The latter should perhaps have been the ones to demand disinfection; for prior to the coming of white people they had been free from tuberculosis, influenza, and similar attributes of civilization.

The twentieth century witnessed a steady increase in the numbers of white women to be found in the north of Alaska, such as the wives who occasionally accompanied their whaling husbands. There were also the dedicated wives of missionaries. In 1908 Barrow's schoolmaster, a Mr. Hawksworth, had his wife with him, as had his predecessor named Spriggs. In 1915 Charles Brower noted that the white population in Barrow comprised, besides himself and his assistant, Mr. Cram and his wife at the church, and Mr. Richardson, accompanied by his wife and two children, at the school. In 1917 a former teacher named Van Valin, who had lived at Icy Cape during 1914-15, became the first scientist to bring his wife and family to Barrow. He became the father of the first white child to be born there. (Dr. Spence, a missionary, and his wife assisted at the delivery.)

Single women, almost always nurses or teachers, began to reach the north coast of Alaska during the second and third decades of the twentieth century. Brower makes mention of a nurse, Miss Jordan, who stayed less than a year at Barrow in 1920, although, after marrying a whaling skipper, she came back there every year (Greist 1968). Three single women were already employed at Barrow Hospital when Eva Alvey Richards arrived further down the coast at Wainwright where, as the only white resident, she became teacher, medical 
practitioner, purveyor of the faith and part-time portrait artist during 1924-26. A quarter of a century later she published an account, illustrated by sketches, of these two years (Richards 1949). It reflects a genuine appreciation of the kindness and wit of the Wainwright Eskimo. As one reads of her undying enthusiasm for the Arctic, however, one begins to suspect that time may have dulled her memories of the less appealing aspects of a region to which she never returned. Certainly, others did not always fare as well as she. Inspectors' reports to the U.S. Bureau of Indian Affairs carry phrases like "Mrs. A. is highly strung and is wearing out" and "You know how a few years affects folks".

One who did survive and endure was, perhaps, the most exemplary woman ever to come to the Arctic coast - the nurse Mollie Ward Greist. Mollie, the wife of a well-to-do Indiana physician, was shocked when her husband suggested giving up his practice and going north as a missionary to the Eskimo. She held out until her fatally-ill elder child died, and then resigned herself and her surviving infant son to her husband's wishes (Greist 1968).

They arrived at Wales, Alaska, in 1920 and stayed there a year before replacing the aging, ailing Dr. and Mrs. Spence at Barrow, where they remained for sixteen long years with only rare periods of leave outside the territory. During their first year (1921), Mollie noted that the white population of Barrow had increased in number from eleven to twelve when the schoolteacher's wife gave birth to a daughter. (William Lopp, head of Alaska's northern schools, always supplied a medical book and a quantity of flannelette to every schoolteacher couple, so that they could, if need be, deliver unaided the baby which would inevitably arrive).

Mollie eventually became head nurse at the hospital, as well as stores manager - no mean undertaking when all household as well as hospital supplies came in on a once-a-year boat that did not always find ice and wind conditions suitable for off-loading at Barrow. That she mastered the art of living a woman's life in the North is indicated by the fact that she got yeast dough to rise in poorly heated quarters, learned how to dress an infant for arctic conditions, carried out her nursing duties under adverse conditions, trained Eskimo nurses, and taught homemaking and hygiene to classes of young Eskimo women. In her memoirs she relates how Eskimo women could toilet-train newborn infants and thus eliminate the need for diapers - a remarkable feat that must be admired by all the women who have ever raised an infant in the Arctic (Greist 1968).

Besides all of her other duties, Mollie, short of cash like most missionaries, ran the U.S. Weather Observatory for many years. By her own admission, she reported more sun-dogs and like phenomena than any other observer before or since; unsuspected cataracts gave a colorful blur to all of her visual measurements. Once, on returning to Barrow after medical leave for eye treatment, she had to wait for good flying weather at Bettles with her pilot, Bobbie Robbins, an employee of the well-known Joe Crosson. Doing the unexpected as always, Mollie, the Presbyterian missionary, shot pool to pass the time.

Mollie was also at home with the famous and near-famous who passed through Barrow. She met Amundsen, a Scottish botanist named Isobel Wylie Hutchinson, and the Lindberghs. With the help of Charles Brower, Mollie and her husband sewed up the maimed bodies of Wiley Post and Will Rogers after their fatal air 
crash near Barrow in 1935, in order that their families might be spared some of the horror of their deaths.

At the same time that Mollie Greist was at Barrow quite a few other women found their way north. In 1931 Ann Lindbergh was the first white woman to be seen by Eskimos at Baker Lake, N.W.T., though she noted in the same year that white nurses, nuns and physicians' wives resided in Aklavik, N.W.T. (Lindbergh 1935). Barrow's white women, by Ann's account, included besides Mrs. Greist, a nurse, a schoolteacher's wife and a radioman's wife.

Charlie Brower the whaler, who was a contemporary of the Greists at Barrow, had married in turn more than one Eskimo woman as influenza and other contingencies took their toll. Many of the offspring, especially those of his second marriage, were sent away to secondary school and college outside the territory. (Mollie recalls that Jennie Brower, a registered nurse from a San Francisco hospital, helped out at the understaffed Barrow hospital during the vacation she spent at home in 1934.) Regrettably, many of these children did not return to Barrow permanently, but those that did, along with Brower's numerous other descendants, became community leaders (Greist 1968).

During the 1940's petroleum exploration brought many white men into the Barrow area, and a limited number of the men employed by the Arctic Contractors Company were followed by their wives, who helped to swell the tiny, white female population of the Barrow area. A few more white women joined husbands stationed at the U.S. Navy's new Arctic Research Laboratory, but usually only for the arctic summer periods. Living conditions in Barrow Camp, four miles from Barrow Village, were far more primitive than those to which most of the wives were accustomed, but they were absolutely luxurious compared to those with which Mollie Greist had had to contend for so many years.

After oil exploration stopped, construction of the Distant Early Warning Line (DEW Line) commenced in 1955 (Reed 1971). A very limited number of wives were allowed housing in Camp, while those not so favoured sometimes attempted to live in Barrow Village where facilities had not changed much since the departure of the Greists in 1936. Only one, Gladys Fravel, had the courage and temperament to stay any length of time in the Village.

The very few - at times, only one - white women, who wintered over in Camp during 1955-56 and 1956-57 found extreme loneliness a problem, and expeditions to Barrow Village were organized to enable them to enjoy additional female companionship. One Camp mother, Mike Dalton, regularly hauled her young fur-wrapped child on his sled the four miles to the Village throughout one winter.

In summer there was an influx of contractors' wives, and a few scientists' wives came too. Except for the wives employed at the Research Laboratory, jobs were, however, denied to women in Camp. The resulting inactivity caused inevitable trouble as the contractors' wives carried on their husbands' feuds - and invented a few new ones of their own. There were days when it seemed that construction of the DEW Line would stop till the warring felines calmed down. As time wore on, a few of these isolated inactive souls began to take more than a nip of the bottle. 
In the summer of 1956 Dr. Ingrith Deyrup became the first unmarried woman scientist at the Laboratory. Those of her sex seemed to be regarded as a dangerous commodity there unless bound by matrimonial ties, and so it was only with some misgiving that she had been allowed to go north. Dr. Deyrup proved all fears to be groundless.

In 1957 Marylou Brewer, wife of the newly appointed Laboratory Director, Max Brewer, arrived with two children, and there began an era of stable family life at the Camp as she went on to become its longest resident woman and the mother of five little Brewers. That same year a start was made on the provision of better accommodation for scientists with families. The Laboratory's Assistant Director, John Schindler, brought his wife Erna north, where she became Marylou's only real rival in staying power. Both women, however, had eventually to leave the Barrow area so that their children might complete secondary schooling.

Living conditions for families in Camp were improving only very slowly during the early 1960's, and the women were beset by difficulties, such as the acute one which arose over facilities for the washing and drying of that nursery necessity, the diaper (practical paper substitutes being not yet on the market). The Camp laundry flatly refused to service these vital garments, and the women found themselves caught between feuding factions in the managements of the Laboratory and the construction company, which would argue endlessly about whose job it was to install or repair a washer or drier. Another difficulty arose from the fact that the U.S. Public Health Service Hospital in Barrow Village only treated white people on an emergency basis, which meant that resident mothers had to form themselves into a flying circus for the purposes of taking their children elsewhere for all but emergency treatment. It was not until 1973 that Barrow Camp had a playroom (an abandoned quonset hut) for its children.

While the Camp was gradually adjusting itself to the idea that men obliged to be away from home for long periods wanted their families near them, the more forward-thinking Canadians were constructing Inuvik, N.W.T. This urban settlement is not dissimilar to any small isolated town in Canada or the United States, except for a number of special circumstances such as that its inhabitants are inclined to consume more alcohol than do people in more southerly areas, and that there are no old white people to speak of. (Retired persons leave not just to avoid the rigorous climate but also because of the cost of housing, which becomes prohibitive when no longer reduced by government subsidy.) As a town which, though located in the far North, enjoys every modern amenity and has the same male-female population ratio as any settlement in a temperate area, Inuvik has become a model much studied by social scientists. In spite, however, of the refinement of the techniques which may now be employed in the taking of opinion polls, housewives were excluded from the data-gathering during a survey of attitudes and their changes in Inuvik on the grounds that they would have no opinions or well-formed attitudes concerning native populations - the subject of the survey (Parsons 1970). One wonders why Canadian social scientists could not have modernized their thinking as much as their builders had modernized the tundra.

Inuvik has welcomed single teachers, nurses and other workers regardless of 
sex or marital status, and in that respect stands in sharp contrast to Barrow Camp where the single woman has been less than acceptable. In the decade following Dr. Deyrup's stay at the Arctic Research Laboratory, only two or three unmarried, white, female scientists trod her path. Single women technicians, hired for private research projects, started appearing at the Laboratory in the late 1960's and early 1970's. The Tundra Biome of the International Biological Programme, which commenced its activities in 1970 (three years after the word "Naval" was incorporated in the Laboratory's title), employed a large number of white women of differing marital situations. They were, by and large, accommodated in quarters markedly inferior to those of their male counterparts. It nevertheless represented an historical achievement that so many of them were actually there!

The same period saw an Icelandic news-reporter become the first woman to alight on the ice island, Arlis II, and Dr. Jean Briggs, then a graduate student in anthropology and familiar with the Arctic Research Laboratory, spent almost two years living with the Canadian Eskimos prior to publishing her book "Never in Anger" (Briggs 1970). Dr. Rita Horner, an unmarried marine biologist, was the first woman to set foot on the ice island designated T-3. By the summer of 1972 the first southern-based single women to be hired by any U.S. construction company for work at Barrow Camp had appeared on the scene.

Some men go north to get away from the company of women, or perhaps to avoid paying alimony to them. Their like will probably never accept females as co-workers. The majority of men employed in the Arctic, however, are succumbing to feminine influence and improving their vocabularies in the process!

Very many other white women have resided in the Alaskan North. For example, two white wives in succession have lived with a bush pilot-author since he arrived in northern Alaska in the early 1940's, and Laboratory pilots' wives have spent extended periods in Barrow Camp, as have the wives of other employees and scientists. Again, government agencies in Barrow Village and along the adjacent coast have employed many white people with families, and single white women as well. Even more white women have lived in the remote areas of Canada, including teachers, hospital personnel, etc., and also the wives of traders, trappers, and miners. Most of these people, despite the length of their stay, do not look upon the "bush" as being home. As Mollie Greist wrote to a friend in 1930, "few American schoolteachers and missionaries have married in this country and remained here to raise their families and make citizens; the rest make a shirt-tail shoot for the States as soon as the first child is six years old". That the situation is not greatly different today is indicated by the very long periods of "outside" leave, which wives, living in remote areas, habitually spend with their children. Even Inuvik, with its large hospital, secondary school system, and suburban atmosphere, is not considered as more than a temporary home by most of its white residents. "Home" is the place that is left outside!

\section{ACKNOWLEDGEMENTS}

The author is indebted to Marylou Brewer, Erna Schindler, David Greist and Peter Vander Sterre for information they supplied personally in 1973. In the Barrow File of the Naval Arctic Research Laboratory's Library she was able to consult: 
the 2 volumes of Edna MacLean's "Barrow Genealogy"; a series of unpublished letters written by various members of staff of the Bureau of Indian Affairs in 1917-19; and, in photo-copy, the unpublished diaries of Charles Brower (original in Stefansson Library, Dartmouth College, Hanover, N.H.), and of William Van Valin for 1914-15 (original in the Archives and Manuscript Collections of the University of Alaska, Fairbanks).

\section{REFERENCES}

BERTON, P. 1967. The Klondike Fever: the Life and Death of the Last Great Gold Rush. New York: Alfred A. Knopf. 457 pp.

BRIGGS, J. L. 1970. Never in Anger: a Portrait of an Eskimo Family. Cambridge, Mass.: Harvard University Press. 379 pp.

CASWELL, J. E. 1971. The sponsors of Canadian arctic exploration. In: W. C. Wonders (ed.), Canada's Changing North. Toronto: McClelland and Stewart, pp. 59-75.

CHEvigny, H. 1942. Lord of Alaska: Baranov and the Russian Adventure. New York: Viking Press. 320 pp.

DAYTON, H. 1859. Thirty Years in the Arctic Regions: on the Adventures of Sir John Franklin. New York: D. W. Evans. 480 pp.

GREIST, M. W. 1968. Nursing under the North Star with Mollie Greist. Bloomington, Indiana: private publication. $172 \mathrm{pp}$.

LINDBERgh, A. M. 1935. North to the Orient. New York: Harcourt, Brace. 255 pp.

LOMEN, C. J. 1954. Fifty Years in Alaska. New York: David McKay. 320 pp.

M'CLINTOCK, F. L. 1860. A Narrative of the Discovery of the Fate of Sir John Franklin and his Companions: the Voyage of the Fox in the Arctic Seas. Philadelphia: J. T. Lloyd, 317 pp.

PARSONS, G. F. 1970. Arctic Suburb: a Look at the North's Newcomers. Ottawa: Department of Indian Affairs and Northern Development. 94 pp.

PEARY, J. D. 1893. My Arctic Journal: a Year among Icefields and Eskimos. New York: Contemporary Publishing Co. $241 \mathrm{pp}$.

Pound, R. 1967. Scott of the Antarctic. New York: Coward McCann. 327 pp.

REED, J. C. and A. G. RONHOVDE. 1971. Arctic Laboratory. Washington, D.C.: Arctic Institute of North America. $748 \mathrm{pp}$.

RICHARds, E. A. 1949. Arctic Mood: a Narrative of Arctic Adventures. Caldwell, Idaho: Caston Printers. 282 pp.

VAN KIRK, s. 1972. Women and the fur trade. The Beaver, 303 (3): 4-21, Winter 1972. 